Engelhart, M. D., Furst, E. J., \& Krathwohl, D. R. (1956). TAXONOMY OF EDUCATIONAL OBJECTIVES The C.lassiiication of Educational Goals HANDBOOK 1 COGNITIVE DOMAIN.

Heong, Y. M., Othman, W. B., Yunos, J. B. M., Kiong, T. T., Hassan, R. Bin, \& Mohamad, M. M. B. (2011). The Level of Marzano Higher Order Thinking Skillsamong Technical Education Students. International Journal of Social Science and Humanity, 121-125.

https://doi.org/10.7763/ijssh.2011.v1.20

Kemendikbud. (2015). Materi Pelatihan Guru Implementasi Kurikulum 2013 Tahun 2015 Sekolah Dasar Luar Biasa.

Majid, A. (2014). Pembelajaran Tematik Terpadu. PT Remaja Rosdakarya.

Mamat, S., Munir, A., Suwendi, Akar, A. T., \& Asro, H. (2005). Pedoman Pelaksanaan Pembelajaran Tematik. Departemen Agama RI.

Nurdin, S., \& Adriantoni. (2016). Kurikulum dan pembelajaran. Rajawali Press.
Pohl, M. (2000). Learning to Think, Thinking to Learn: Models and Strategies to Develop a Classroom Culture of Thinking. 98.

Prastowo, A. (2011). Panduan kreatif membuat bahan ajar inovatif. Yogyakarta: DIVA press.

Rusman. (2013). Model Pembelajaran Mengembangkan Profesionalisme Guru, Model Pembelajaran Mengembangkan Profesionalisme Guru. Rajawali Pers.

Sani, R. A. (2013). Inovasi pembelajaran.

Saputra, H. (2016). Pengembangan Mutu Pendidikan Menuju Era Global: Penguatan Mutu Pembelajaran dengan Penerapan HOTS (High Order Thinking Skills). In SMILE's Publishing (Vol. 1). Smile's Indonesia Instutite.

Suradika, Agus. (2000). Metode Penelitian Sosial. Jakarta: UMJ Press.

Trianto. (2010). Model pembelajaran terpadu: konsep, strategi, dan implementasinya dalam kurikulum tingkat satuan pendidikan (KTSP). Bumi Aksara. 


\title{
PENGEMBANGAN BAHAN PEMBELAJARAN BERBASIS MODUL ELEKTRONIK BERBANTUAN FLIPBOOK MAKER PADA MATA PELAJARAN FISIKA SMA
}

\author{
Widya Nuraeni \\ SMA Negeri 14, Bekasi, Jawa Barat \\ widya.nuraeni88@gmail.com
}

\begin{abstract}
The purpose of this study was to develop learning materials in the form of electronic modules assisted by flipbooks to high school physics learning. The electronic module developed refers to the Dick and Carey research and development model. The research method used is the Research and Development Borg and Gall method. To determine the quality and effectiveness of the electronic modules that have been compiled, then a validity test is carried out involving subject matter experts, learning design experts, colleagues, and students who will become users of electronic modules. The data obtained were analyzed descriptively quantitatively and the assessment data from the validators were analyzed descriptively qualitatively. The data is used as a reference for revising the product so that it is suitable for use.
\end{abstract}

Keywords: Electronic Module; Flipbook Maker; Dick and Carey; Physics

\section{ABSTRAK}

Tujuan penelitian ini adalah untuk mengembangkan bahan pembelajaran berupa modul elektronik berbantuan flipbook untuk pembelajaran fisika SMA. Modul elektronik yang dikembangkan mengacu pada model penelitian dan pengembangan Dick and Carey. Metode penelitian yang digunakan adalah metode Research and Development Borg and Gall. Untuk mengetahui kualitas dan efektivitas modul elektronik yang telah disusun, selanjutnya dilakukan uji validitas yang melibatkan ahli materi pelajaran, ahli desain pembelajaran, teman sejawat serta peserta didik yang akan menjadi pengguna modul elektronik. Data yang diperoleh dianalisis secara deskriptif kuantitatif dan data penilaian dari validator dianalisis secara deskriptif kualitatif. Data tersebut dijadikan acuan untuk merevisi produk agar layak digunakan.

Kata kunci: Modul Elektronik; Flipbook Maker; Dick and Carey; Fisika

\section{PENDAHULUAN}

Komponen utama yang paling penting dalam suatu sistem pembelajaran salah satunya adalah bahan pembelajaran (instructional materials). Dengan tersedianya bahan pembelajaran di sekolah akan sangat membantu proses pembelajaran. Bahan pembelajaran memuat materi atau isi pembelajaran serta dapat mendukung kegiatan pembelajaran (Dewi et al., 2020).

Bahan pembelajaran dibagi menjadi beberapa kelompok, bahan cetak dan bahan non cetak. Bahan ajar cetak berupa buku, modul, handout, dan lembar kerja peserta didik (LKPD) sedangkan bahan non cetak dapat berupa display, audio, video, modul elektronik.

Modul elektronik dapat mempermudah guru dalam menyampaikan materi pembelajaran serta dapat membuat peserta didik lebih aktif dan interaktif dalam kegiatan pembelajaran. Menurut Winarko dkk. modul elektronik merupakan media pembelajaran yang berisi tentang materi, metode, batasan, dan metode penilaian yang dibuat secara urutan untuk mencapai kemampuan peserta didik yang diharapkan. Di dalam modul elektronik materi 
pembelajaran dikemas secara utuh (Winarko et al., 2013). Peserta didik dapat belajar secara mandiri dan lebih aktif sesuai dengan kemampuan belajarnya.

Salah satu teknologi yang dapat digunakan untuk mendesain bahan pembelajaran elektronik adalah flipbook. Penggunaan flipbook dapat membantu guru dalam menyajikan bahan pembelajaran elektronik yang lebih menarik (RUSNILAWATI \& Gustiana, 2018). Flipbook dapat menyajikan gambar, video, tulisan, animasi, dan sebagainya sehingga pembelajaran tidak monoton dan peserta didik lebih tertarik.

Modul elektronik berbantuan flipbook dapat digunakan sebagai media pembelajaran digital yang cocok untuk pembelajaran fisika, dengan fitur flipbook dapat menyisipkan audio, gambar, video serta animasi bahkan dapat menggunakan $Q R$ barcode dan Augmented Reality. Dengan segala fitur yang ada dapat membantu peserta didik lebih mudah memahami materi pembelajaran. Modul elektronik berbantuan flipbook ini juga sangat praktis tidak seperti modul cetak yang telah ada, modul elektronik ini dapat diakses guru dan peserta didik dimanapun dan kapan saja karena dapat disajikan dengan berbagai perangkat, seperti laptop, tablet, smartphone. Untuk itu, penulis tertarik melakukan penelitian berjudul "Pengembangan Bahan Pembelajaran Berbasis Modul Elektronik Berbantuan Flipbook Maker Pada Mata Pelajaran Fisika SMA". Rumusan masalahnya sebagai berikut: (a) Bagaimanakah proses pengembangan Bahan pembelajaran elektronik berbantuan flipbook maker untuk mata pelajaran Fisika SMA (b) Apakah bahan pembelajaran elektronik berbantuan flipbook maker yang dikembangkan layak untuk digunakan dalam pembelajaran Fisika SMA dan (c) Apakah modul elektronik berbantuan flipbook maker dapat menciptakan suasana belajar lebih kondusif dan bermakna sehingga mampu meningkatkan gairah belajar peserta didik.

\section{KAJIAN LITERATUR \\ - BAHAN PEMBELAJARAN}

Penelitian Suradika dkk. tentang pengaruh bahan instruksional dan latar belakang pendidikan terhadap hasil belajar pendidikan agama Islam menunjukkan hasil bahwa Bahan pembelajaran merupakan variabel yang berpengaruh terhadap hasil belajar pendidikan agama Islam. "Instructional material is a variable that affects the learning outcomes of Islamic education. Students who were given lectures using Independent instructional materials ( $X$ $=79.45)$ were higher than those who used PBS instructional materials $(X=75.6)$. Terjemahannya "bahan pembelajaran merupakan variabel yang mempengaruhi hasil belajar pendidikan agama Islam. Mahasiswa yang diberikan perkuliahan dengan menggunakan bahan pembelajaran mandiri $(\mathrm{X}=79,45)$ lebih tinggi dibandingkan dengan mahasiswa yang menggunakan bahan pembelajaran PBS $(\mathrm{X}=$ 75,6) (Suradika et al., 2020).

Bahan pembelajaran yang digunakan dalam proses pembelajaran dapat meningkatkan mutu pembelajaran apabila dikembangkan sesuai dengan kebutuhan peserta didik dan dimanfaatkan secara benar. Dengan memanfaatkan bahan pembelajaran 
yang dirancang sesuai dengan kebutuhan pembelajaran, peserta didik diarahkan untuk menjadi pembelajar yang aktif karena mereka dapat membaca atau mempelajari materi yang terdapat pada bahan ajar terlebih dahulu sebelum mengikuti pembelajaran dalam kegiatan belajar dan mengajar.

Seorang guru harus mempersiapkan proses pembelajaran dengan baik, juga harus mempunyai wawasan dan kecakapan terhadap penguasaan berbagai bahan pembelajaran yang sangat penting dalam proses pembelajaran. Nasution berpendapat bahwa bahan pembelajaran merupakan salah satu perangkat materi atau substansi pembelajaran yang disusun secara sistematis, serta menampilkan secara utuh dari kompetensi yang akan dikuasai peserta didik dalam kegiatan pembelajaran (Nasunito, 2000).

Lebih lanjut dapat dijelaskan posisi merancang bahan pembelajaran dalam suatu sistem pembelajaran. Suradika menjelaskan komponen-komponen dari suatu set bahan instruksional dan prosedur yang akan digunakan bersama bahan-bahan tersebut untuk mencapai hasil belajar tertentu. Lima komponen strategi instruksional adalah (a) kegiatan pra-instruksional, (b) penyajian informasi, (c) partisipasi siswa, (d) tes, dan (e) tindak lanjut. Strategi instruksional digunakan untuk menilai apakah bahan yang dikembangkan atau yang tersedia sudah memenuhi syarat atau masih perlu disesuaikan sebelum digunakan. Penilaian bahan dilakukan guna menentukan apakah bahan (a) cukup menarik, (b) sesuai isinya, (c) tepat urutannya, (d) mempunyai informasi yang dibutuhkan, (e) memiliki soal latihan, (f) terdapat jawaban latihan yang jelas untuk usaha-usaha perbaikan, dan (g) terdapat petunjuk bagi siswa yang mengarahkan mereka dari satu kegiatan ke kegiatan belajar lainnya. Pengembangan bahan instruksional merupakan sub-sistem dari pengembangan sistem instruksional (Suradika, 2000b).

Bahan pembelajaran dapat dikelompokkan ke dalam kelompok besar, yaitu bahan cetak dan bahan non cetak. Bahan pembelajaran cetak meliputi: handout, berisi point-point penting dari materi pelajaran; modul, bahan ajar yang disusun guru dalam bentuk tertentu untuk dibaca atau dipelajari peserta didik secara mandiri; buku, merupakan kumpulan kertas yang berisi ilmu pengetahuan hasil analisis seseorang dalam bentuk tertulis; Lembar Kerja Peserta Didik, LKPD merupakan materi ajar yang disusun sedemikian rupa sehingga peserta didik dapat mempelajari materi pembelajaran tersebut secara mandiri. Bahan pembelajaran non cetak meliputi: audio, bahan ajar yang digunakan untuk penyampaian pesan atau informasi melalui bunyi dan suara sehingga dapat diterima oleh peserta didik; audiovisual, bahan pembelajaran yang digunakan untuk penyampaian pesan atau informasi melalui bunyi atau suara dan gambar sehingga komunikasi menjadi lebih bervariasi; multimedia interaktif, penggabungan bahan pembelajaran lainnya seperti teks, grafik, animasi, audio dan gambar video sehingga menjadi kumpulan yang menarik, multimedia interaktif ada dua jenis pertama multimedia interaktif online seperti situs web, gmail, blog sedangkan multimedia offline seperti CD interaktif, media pembelajaran berbasis software (Adobe Flash), modul elektronik. 
Ahli lain, Suparman membedakan tiga bentuk pengembangan bahan instruksional berdasarkan bentuk kegiatan instruksional, yaitu untuk (a) pembelajaran mandiri, di mana pengajar bertindak sebagai fasilitator dan siswa belajar mandiri, dilakukan pengembangan bahan instruksional mandiri, (b) pembelajaran konvensional, di mana pengajar sebagai sumber tunggal dan siswa belajar darinya, dikembangkan bahan instruksional konvensional, dan (c) pembelajaran PBS (Pengajar-Bahan-Siswa) di mana pengajar bertindak sebagai penyaji bahan belajar yang dipilihnya, dikembangkan bahan instruksional PBS (Suparman, 2014).

Dalam penelitian ini, bentuk bahan instruksional yang digunakan adalah bahan instruksional elektronik atau yang dikenal dengan e-module.

\section{- MODUL ELEKTRONIK}

Modul pada bahan cetak ditransformasikan penyajiannya ke dalam bentuk elektronik sehingga lahir istilah baru yaitu modul elektronik dikenal dengan $e$ module (Winatha, 2018). Modul elektronik merupakan alat atau sarana pembelajaran yang berisi materi, metode, batasan-batasan, serta cara mengevaluasi yang dirancang secara sistematis dan menarik untuk mencapai kompetensi yang diharapkan sesuai dengan tingkat kompleksitasnya secara elektronik (Imansari \& Sunaryantiningsih, 2017). Modul elektronik disajikan secara elektronik dengan menggunakan hard disk, disket, $\mathrm{CD}$, atau flashdisk dan dapat dibaca menggunakan komputer atau alat pembaca buku elektronik, bahkan smartphone.
Secara konsep, tidak ada perbedaan yang signifikan antara modul berbasis cetak dan modul elektronik. Komponen-komponen yang terdapat dalam modul berbasis cetak juga terdapat di dalam modul elektronik, seperti rumusan tujuan, petunjuk penggunaan, materi, lembar kerja, penilaian dan lain-lain. Perbedaan antara modul berbasis cetak dan modul elektronik hanya terletak pada penyajian secara fisik. Modul membutuhkan kertas sebagai bahan cetak, sedangkan modul elektronik membutuhkan perangkat komputer atau smartphone untuk menjalankannya. Dengan modul elektronik setiap orang dapat secara mandiri dengan belajar kapan saja dan di mana saja.

\section{- FLIPBOOK MAKER}

Flipbook merupakan media yang dikemas dengan tampilan menarik dan mempermudah dalam proses pembelajaran. Bentuk penyajian flipbook atau digital book dalam media belajar buku secara virtual. Dengan menggunakan flipbook peserta didik jadi lebih interaktif selama proses pembelajaran berlangsung serta lebih menarik dan menyenangkan karena disajikan ke dalam format elektronik yang didalamnya mampu menampilkan simulasi-simulasi yang interaktif dengan memadukan teks, gambar, audio, video, animasi, dan navigasi.

Flipbook maker termasuk software yang mempunyai fungsi setiap halaman yang dibuka akan menjadi layaknya sebuah buku. Software ini dapat membuat dan mengubah file $p d f$, gambar atau foto menjadi sebuah buku atau album fisik ketika membuka setiap halamannya. Hasil akhir yang didapat akan disimpan dalam format swf, exe, .html. Flipbook maker juga dapat membuat e-book, 
e-module, e-paper dan e-magazine. Selain teks flipbook maker juga dapat menyisipkan gambar, grafik, suara, link, dan video lembar kerja. Dengan memuat tampilan-tampilan menarik pada modul elektronik berbantuan flipbook maker ini peserta didik akan lebih tertarik untuk belajar

\section{METODE PENELITIAN}

Pendekatan yang digunakan dalam penelitian ini adalah pendekatan kualitatif. Jenis penelitiannya deskriptif, yaitu suatu jenis penelitian yang berusaha menggambarkan secara komprehensif suatu fenomena sosial tertentu (Suradika, 2000). Metode penelitiannya adalah metode penelitian dan pengembangan atau $R$ and $D$ (Research and Development). Dipilihnya $R$ and $D$ ini karena untuk menghasilkan produk tertentu dan menguji keefektifan produk tersebut. Untuk dapat menghasilkan produk tertentu digunakan penelitian yang bersifat analisis kebutuhan dan untuk menguji keefektifan produk tersebut supaya dapat berfungsi di masyarakat luas, diperlukan penelitian untuk menguji keefektifan produk tersebut (Sugiyono, 2019).

$$
\text { Model pengembangan yang }
$$
digunakan dalam pengembangan bahan pembelajaran berbasis modul elektronik berbantuan flipbook pada mata pelajaran Fisika adalah model pengembangan pembelajaran (instructional systems development/ISD) Dick and Carey yang telah disesuaikan dengan keperluan pengembangan. Selain itu, modul elektronik mata pelajaran Fisika kelas XII dikembangkan berdasarkan pada kompetensi dasar (KD) 3.4 Menganalisis fenomena induksi elektromagnetik dalam kehidupan sehari-hari dan 4.4 Melakukan percobaan tentang induksi elektromagnetik berikut presentasi hasil percobaan dan pemanfaatannya dalam kehidupan sehari-hari Pemilihan model pengembangan pembelajaran Dick and Carey didasarkan pada pertimbangan praktis dan akademis, di antaranya: 1) Model Dick and Carey relatif lebih sederhana tetapi tahapannya dan komponennya yang dikembangkan lebih rinci, 2) dapat menerapkan beberapa tujuan pembelajaran serta pengembangan ranah kognitif, afektif dan psikomotorik, 3) memaparkan evaluasi yang variatif, 4) memiliki kekuatan dalam menganalisis dan mengevaluasi pembelajaran, 5) langkahnya lengkap sampai pada tingkat produk yang jelas (Natsir, 2017).

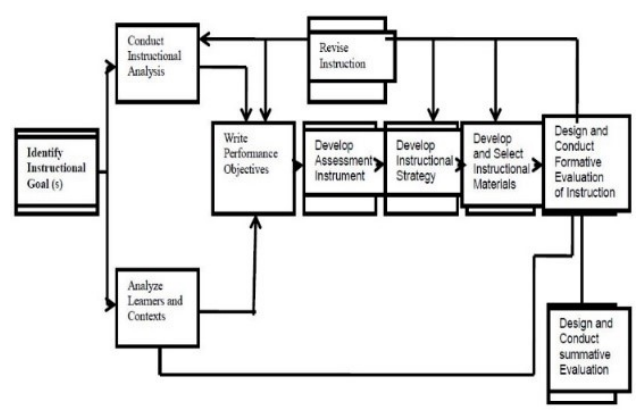

Bagan 1 Sistem Desain Pembelajaran

Penyusunan buku ajar ini mengacu pada tahapan pengembangan Dick, Carey and Carey yang terdiri dari sepuluh tahapan, yaitu 1) mengidentifikasi tujuan pembelajaran (menggunakan front-end analysis), 2) melakukan analisis pembelajaran, 3) mengidentifikasi kemampuan awal dan karakteristik peserta didik, 4) menyusun tujuan pembelajaran, 5) mengembangkan asesment atau instrumen penelitian, 6) mengembangkan strategi pembelajaran, 7) mengembangkan modul elektronik berbantuan flipbook maker dan 
memilih materi pembelajaran, 8) merancang dan melaksanakan evaluasi formatif, 9) Mengevaluasi modul elektronik, melakukan revisi; dan 10) merancang dan melaksanakan evaluasi sumatif (Dick et al., 2005).

Data yang diperoleh dari uji coba produk pengembangan Modul Elektronik berbantuan Flipbook Maker mata pelajaran fisika bersifat kualitatif. Data kualitatif didapat dari data dengan penyebaran angket kepada ahli isi bidang studi, ahli desain, tenaga pendidik dan peserta didik.

Uji coba ahli melibatkan ahli materi pelajaran dan ahli desain pembelajaran. Penentuan ahli yang akan melakukan pengujian didasarkan pada kualifikasi akademik dan pengalaman yang dimilikinya. Untuk kualitas dan efektivitas materi pelajaran diuji oleh Dosen pengampu Mata Kuliah Fisika di Universitas Negeri Jakarta sedangkan efektivitas media dan desain pembelajaran divalidasi oleh dosen bidang Pendidikan di Universitas Muhammadiyah Jakarta. Pada uji coba tenaga pendidik dilakukan oleh teman sejawat sebanyak 1 orang.

Uji coba kelompok kecil dilakukan terhadap dua belas orang peserta didik di SMA Negeri 14 Bekasi, dua belas subjek uji tersebut terdiri dari empat orang peserta didik berkemampuan tinggi, empat orang berkemampuan rata-rata, dan empat orang peserta didik berkemampuan rendah. Menurut Dick, dkk. delapan sampai dua puluh orang subjek yang digunakan pada uji kelompok kecil sudah dianggap mencukupi (Dick et al., 2005)

Sedangkan uji coba lapangan atau kelompok besar dilakukan pada peserta didik kelas 12 di SMA Negeri 14 Bekasi sebanyak satu kelas yang berjumlah 36 orang, tidak termasuk peserta didik yang telah dikenakan uji coba kelompok kecil. Prosedur dan kondisi pada uji coba lapangan atau kelompok besar relatif sama dengan uji pada kelompok kecil. Perbedaannya hanyalah pada jumlah subjek yang digunakan. Uji coba lapangan (kelas) dapat dilakukan pada peserta didik dengan minimal 30 orang (Dick et al., 2005).

Data dianalisis secara deskriptif kuantitatif setelah data terkumpul. Data penilaian yang diperoleh dari validator dianalisis secara deskriptif kualitatif dan dijadikan sebagai acuan untuk merevisi produk sehingga menghasilkan produk yang layak. Materi dan desain produk yang dikembangkan divalidasi oleh validator dengan menggunakan lembar validasi. Hasil penilaian terhadap seluruh aspek diukur dengan Skala Likert.

Selanjutnya data penelitian dianalisis dengan perhitungan persentase skor, yaitu dengan membagi jumlah suatu skor dengan jumlah skor secara keseluruhan (Suradika, 2000) dengan rumus sebagai berikut:

Persentase Skor $=\frac{\sum x}{\sum x_{i}} \times 100 \%$

Skor yang diperoleh selanjutnya skor diinterpretasikan kedalam kategori kelayakan sesuai tabel berikut.

Tabel 1 Kriteria Kelayakan Berdasarkan Persentase Skor
$0-20$
Kriteria

Sangat Kurang 


\begin{tabular}{c|c}
$21-40$ & Kurang \\
$41-60$ & Cukup \\
$61-80$ & Layak \\
$81-100$ & Sangat Layak
\end{tabular}

Sumber: Ridwan dalam Yuniati, 2019: 21

Pencapaian persentase skor kelayakan yang dihasilkan $\leq 61 \%$ atau dalam kategori cukup maka akan dilakukan revisi. Revisi modul elektronik dilakukan pada bagianbagian yang mengalami kekurangan setelah didapatkan saran atau catatan yang didapatkan oleh peneliti dari para validator maupun saat kegiatan uji coba.

\section{PEMBAHASAN}

Langkah awal dalam proses merancang modul elektronik berbantuan flipbook maker yang paling penting adalah mengidentifikasi tujuan pembelajaran. Proses ini harus dilakukan dengan baik, maka modul elektronik yang dihasilkan akan sesuai dengan kebutuhan peserta didik. Banyak cara dalam mengidentifikasi tujuan pembelajaran, tetapi terdapat empat metode yang paling sering digunakan, yaitu: pendekatan pakar, pendekatan kurikulum, pendekatan mandat administratif dan pendekatan teknologi kerja (Carpenter \& MacFarlane, 2018; Dick et al., 2005; Gooder \& Cantwell, 2017; Jacob \& Gokbel, 2018; in Sardi, 2018)

$$
\text { Proses identifikasi tujuan }
$$
pembelajaran pada penelitian ini dengan melakukan kombinasi antara pendekatan pakar, pendekatan kurikulum dan pendekatan teknologi kerja. Pendekatan pakar dan pendekatan kurikulum dilakukan dengan cara observasi, wawancara, angket pendapat dosen mengenai tujuan pembelajaran yang perlu dicapai. Pendekatan teknologi kerja, tujuan pembelajaran ditetapkan sebagai respons terhadap masalah atau peluang dalam pembelajaran serta perkembangan teknologi terbaru terkait aktivitas pembelajaran.

Tahap selanjutnya adalah menentukan langkah demi langkah apa yang harus dilakukan untuk mencapai tujuan pembelajaran yang telah dilakukan serta melihat subskills yang diperlukan untuk penguasaan tujuan secara komprehensif. Proses ini ditempuh dengan melakukan berbagai telaah pada kurikulum yang ada. Secara umum yang ditelaah dari kurikulum adalah landasan filosofi yang dijadikan dasar dalam pengembangan kurikulum. Setelah mendapatkan hasil telaah selanjutnya digunakan untuk proses penyusunan silabus. Penting juga untuk diperhatikan adalah urutan materi yang dibahas pada silabus. Beberapa materi pengenalan dan kemampuan dasar ditempatkan dibagian awal, sementara topik yang agak lebih kompleks dibahas pada bagian akhir.

Hasil telaah kurikulum dan penyusunan silabus dapat dikombinasikan dengan analisis tingkah laku dan karakteristik peserta didik. Dari hasil pengamatan langsung dan analisis hasil belajar akan dapat dilihat hasil karakteristik dan latar belakang peserta didik yang berbeda serta memiliki gaya belajar yang berbeda dan tingkat kematangan berpikir yang bervariasi. Modul elektronik yang akan dibuat harus disesuaikan dengan kemampuan bahasa dan perkembangan intelektual yang dimiliki peserta didik. Modul elektronik dibuat 
dengan struktur kalimat yang efektif dan bahasa yang mudah dipahami.

Kualitas dan efektivitas modul elektronik yang telah disusun dapat diketahui dengan dilakukan uji validitas yang melibatkan ahli materi pelajaran, ahli desain pembelajaran serta peserta didik yang akan menjadi pengguna modul elektronik. Instrumen uji validitas mengikuti panduan yang dikeluarkan oleh Badan Standar Nasional Pendidikan. Lembar validasi dibuat dengan menggunakan skala Likert berupa angket. Akan terdapat empat pilihan jawaban pada instrumen yaitu sangat kurang (SK), kurang (K), baik (B) dan sangat baik (SB) yang secara berturut-turut dikonversi menjadi nilai 1, 2, 3 dan 4. Terdapat 3 instrumen yang akan digunakan untuk mengetahui kualitas produk yaitu: 1) Lembar uji kualitas materi pelajaran, 2) Lembar uji kualitas media pembelajaran, 3) Lembar uji efektivitas modul elektronik pada peserta didik.

Pada lembar uji kualitas materi pelajaran akan terdapat beberapa indikator dalam aspek kelayakan isi, aspek kelayakan penyajian dan penilaian bahasa. Isi dari aspek kelayakan: kelengkapan, keluasan dan kedalaman materi. Keakuratan materi perlu diperhatikan terkait konsep, prinsip, fakta, contoh ataupun gambar dan ilustrasi yang digunakan. Aspek kelayakan penyajian mempunyai indikator seperti konsistensi sistematika sajian serta kelengkapan penyajian. Terakhir aspek bahasa dinilai ketepatan dan keefektifan kalimat, keruntutan dan keterpaduan alur pikir serta kesesuaian dengan tingkat perkembangan peserta didik.
Ahli media dan desain pembelajaran menilai lembar uji kualitas media pembelajaran. Instrumen ini menekankan pada aspek kelayakan penyajian, penilaian bahasa dan kelayakan grafika. Aspek kelayakan penyajian dan penilaian bahasa, indikator yang digunakan hampir sama dengan lembar uji kualitas materi pelajaran.

Instrumen ketiga adalah lembar uji efektivitas modul elektronik untuk peserta didik. Instrumen ini digunakan pada uji coba kelompok dan uji coba lapangan atau kelompok besar. Adapun beberapa bagian yang diuji adalah aspek tampilan, aspek penyajian materi dan aspek manfaat. Harus diperhatikan pada aspek tampilan adalah menarik dan sesuai gambar yang disajikan dengan materi pelajaran serta tingkat keterbacaan tulisan pada modul elektronik. Aspek penyajian materi dapat dilihat kemudahan dalam memahami materi serta keruntutan materi belajar yang disajikan. Aspek manfaat memiliki indikator: ketertarikan menggunakan modul elektronik, kemudahan belajar dengan menggunakan modul elektronik yang ditulis serta tingkat pemahaman materi.

Strategi pembelajaran untuk mendesain berbagai aktivitas pembelajaran menggunakan model pembelajaran discovery learning yang dapat memunculkan karakter pelajar Pancasila. Materi yang dipilih dalam pengembangan modul elektronik adalah induksi elektromagnetik tampilan modul elektromagnetik menggunakan flipbook maker. Modul elektronik akan direvisi setelah dilakukan validasi. Revisi dilakukan berdasarkan data materi, ahli media dan pembelajaran serta responden teman sejawat 
dan peserta didik. Pada tahapan ini penelitian belum dilaksanakan. Tahapan terakhir adalah mendesain dan melaksanakan evaluasi sumatif, evaluasi sumatif dilakukan setelah produk telah selesai dievaluasi secara formatif serta direvisi berdasarkan data dari evaluasi formatif. Tahapan ini belum dilaksanakan, akan dilaksanakan pada penelitian selanjutnya.

Dengan perkembangan teknologi modul elektronik merupakan inovasi pembelajaran fisika di era abad 21. Dengan mengembangkan pembelajaran berbasis teknologi sangat memudahkan peserta didik untuk memahami berbagai konsep yang sulit untuk dipahami. Dengan mengembangkan modul elektronik berbantuan flipbook maker salah satu bentuk upaya dalam mendukung pembelajaran di era digital. Modul elektronik berbantuan flipbook maker dapat digunakan secara jarak jauh, peserta didik tidak perlu hadir ke kelas untuk menggunakan modul ini. Peserta didik dapat mengakses modul dimana saja dan kapan saja. Keunggulan lainnya adalah materi disajikan dalam bentuk animasi yang dapat memudahkan peserta didik dalam memahami pembelajaran fisika.

\section{PENUTUP}

Penelitian yang telah dilakukan di SMA Negeri 14 Bekasi untuk pengembangan bahan pembelajaran berbasis modul elektronik berbantuan flipbook maker dapat disimpulkan sebagai berikut:

1. Bahan pembelajaran elektronik berbantuan flipbook maker ini dikembangkan dengan metode penelitian dan pengembangan (Research and Development) dengan model Dick and Carey. Modul elektronik ini disajikan dengan memvisualisasikan konsep yang terdapat pada materi Induksi Elektromagnetik dengan beberapa media di antaranya gambar, video, animasi ataupun multimedia pendukung lainnya. Penelitian awal menunjukkan bahwa modul elektronik ini sangat dibutuhkan oleh peserta didik dan juga prototype dari modul elektronik ini sudah berhasil dikembangkan.

2. Bahan pembelajaran elektronik berbantuan flipbook maker yang dikembangkan layak untuk digunakan dalam pembelajaran Fisika SMA.

3. Setelah peserta didik menggunakan modul elektronik berbantuan flipbook maker untuk materi induksi elektronik, peserta didik lebih mudah dalam memahami materi. Modul elektronik berbantuan flipbook maker merupakan salah satu media yang dapat menciptakan suasana belajar lebih kondusif dan bermakna sehingga mampu meningkatkan gairah belajar peserta didik.

\section{REFERENSI}

Carpenter, J. P., \& MacFarlane, M. R. (2018). Educator perceptions of districtmandated Edcamp unconferences. Teaching and Teacher Education, 75, 71-82.

https://doi.org/10.1016/J.TATE.2018. 06.002

Dewi, N. N. E., Santoso, H., \& Lepiyanto, A. (2020). PENGEMBANGAN MODUL BIOLOGI METODE POE (PREDICT, OBSERVE, EXPLAIN) DISERTAI NILAI KARAKTER MATERI SISTEM RESPIRASI. Quagga: Jurnal Pendidikan Dan Biologi, 12(2), 211. https://doi.org/10.25134/quagga.v12i 2.2898 
Dick, W., Carey, L., \& Carey, J. O. (2005). The Systematic Design of Instruction (6th ed.). Pearson.

Gooder, V., \& Cantwell, S. (2017). Student Experiences With a Newly Developed Concept-Based Curriculum. Teaching and Learning in Nursing, 12(2), 142147.

https://doi.org/10.1016/J.TELN.2016. 11.002

Imansari, N., \& Sunaryantiningsih, I. (2017). Pengaruh Penggunaan E-Modul Interaktif Terhadap Hasil Belajar Mahasiswa pada Materi Kesehatan dan Keselamatan Kerja. VOLT: Jurnal Ilmiah Pendidikan Teknik Elektro, 2(1),

11. https://doi.org/10.30870/volt.v2i1.14 78

Jacob, W. J., \& Gokbel, V. (2018). Global higher education learning outcomes and financial trends: Comparative and innovative approaches. International Journal of Educational Development, 58 , 5-17. https://doi.org/10.1016/J.IJEDUDEV. 2017.03.001

Winarko, A. S., Sunarno, W., Masykuri, M., Studi, P., Sains, P., Pascasarjana, P., \& Sebelas, U. (2013). Pengembangan Modul ElektronikBerbasis POEI (Prediksi, Observasi, Eksperimen, Interpretasi)Pada Materi Sistem Indera Kelas XI SMA Negeri Ponorogo. Bioedukasi, 6(2), 58-75. https://jurnal.fkip.uns.ac.id/index.php /biologi/article/view/5530
Nasunito, S. (2000). Berbagai Pendekatan Dalam Proses Belajar Dan Mengajar. Bumi Aksara.

RUSNILAWATI, R. E. G., \& Gustiana, E. (2018). THE DEVELOPMENT OF ELECTRONIC TEACHING MATERIALS BY FLIPBOOK ASSISTANCE BASED PROBLEM SOLVING SKILL WITH CTL APPROACH ON LEARNING MATHEMATICS CLASS V. Profesi Pendidikan Dasar, 1(2), 223. https://doi.org/10.23917/ppd.v1i2.54 50

Sardi, A. (2018). PENGEMBANGAN BUKU AJAR TEKNIK LABORATORIUM BIOLOGI DENGAN MENGGUNAKAN MODEL DICK AND CAREY. Jurnal Biotek, 6(2), 37. https://doi.org/10.24252/jb.v6i2.6399

Sugiyono. (2019). Metode Penelitian Kuantitatif, Kualitatif, dan $R \& D$ (Alfabeta).

Suparman, M. A. (2014). Desain Instruksional Modern : Panduan Para Pengajar Dan Inovator Pendidikan (N. I. Sallama, Ed.). Erlangga.

Suradika, A. (2000). Metode Penelitian Sosial. UMJ Press.

Suradika, A. (2000). Pengantar statistik sosial. UMJ Press.

Suradika, A., Winata, W., Wicaksono, D., Hadi, M. S., \& Rifqiyati. (2020). The Influence of Instructional Materials and Educational Background on the Learning Outcomes of Islamic Education. Solid State Technology, 
63(6),

1027-1043.

http://solidstatetechnology.us/index.p hp/JSST/article/view/2185

Winatha, K. R. (2018). Pengembangan Emodul Interaktif Berbasis Proyek Mata Pelajaran Simulasi Digital.
Jurnal Pendidikan Teknologi Dan

Kejuruan, 15(2),

188.

https://doi.org/10.23887/jptk-

undiksha.v15i2.14021 